\title{
PROPAGATION OF POSITIVE EFFECTS OF POSTDISASTER POLICIES THROUGH SUPPLY CHAINS
}

EVIDENCE FROM THE GREAT EAST JAPAN EARTHQUAKE AND TSUNAMI

Yuzuka Kashiwagi and Yasuyuki Todo

NO. 604

January 2020
ADB ECONOMICS WORKING PAPER SERIES 


\section{ADB Economics Working Paper Series}

\section{Propagation of Positive Effects of Postdisaster Policies through Supply Chains: Evidence from the Great East Japan Earthquake and Tsunami}

Yuzuka Kashiwagi and Yasuyuki Todo

No. 604 | January 2020
Yuzuka Kashiwagi (yuzu-26@akane.waseda.jp) is a research fellow of Japan Society for the Promotion of Science and a doctoral candidate of the Graduate School of Economics, Waseda University.

Yasuyuki Todo (yastodo@waseda.jp) is a professor in the Faculty of Political Science and Economics, Waseda University, and a faculty fellow at the Research Institute of Economy, Trade and Industry.

This paper was prepared as background material for the Asian Development Outlook (ADO) 2019 theme chapter on "Strengthening Disaster Resilience." The authors would like to thank Benno Ferrarini, Thomas McDermott, Ilan Noy, Yasuyuki Sawada, and participants at the ADO workshop for their useful comments. 
(C) 2020 Asian Development Bank 6 ADB Avenue, Mandaluyong City, 1550 Metro Manila, Philippines

Tel +632 8632 4444; Fax +63286362444

www.adb.org

Some rights reserved. Published in 2020.

ISSN 2313-6537 (print), 2313-6545 (electronic)

Publication Stock No. WPS200003-2

DOI: http://dx.doi.org/10.22617/WPS200003-2

The views expressed in this publication are those of the authors and do not necessarily reflect the views and policies of the Asian Development Bank (ADB) or its Board of Governors or the governments they represent.

ADB does not guarantee the accuracy of the data included in this publication and accepts no responsibility for any consequence of their use. The mention of specific companies or products of manufacturers does not imply that they are endorsed or recommended by ADB in preference to others of a similar nature that are not mentioned.

By making any designation of or reference to a particular territory or geographic area, or by using the term "country" in this document, $A D B$ does not intend to make any judgments as to the legal or other status of any territory or area.

This work is available under the Creative Commons Attribution 3.0 IGO license (CC BY 3.0 IGO)

https://creativecommons.org/licenses/by/3.0/igo/. By using the content of this publication, you agree to be bound by the terms of this license. For attribution, translations, adaptations, and permissions, please read the provisions and terms of use at https://www.adb.org/terms-use\#openaccess.

This CC license does not apply to non-ADB copyright materials in this publication. If the material is attributed to another source, please contact the copyright owner or publisher of that source for permission to reproduce it. $\mathrm{ADB}$ cannot be held liable for any claims that arise as a result of your use of the material.

Please contact pubsmarketing@adb.org if you have questions or comments with respect to content, or if you wish to obtain copyright permission for your intended use that does not fall within these terms, or for permission to use the ADB logo.

Corrigenda to ADB publications may be found at http://www.adb.org/publications/corrigenda.

Note:

In this publication, “\$” refers to United States dollars.

The ADB Economics Working Paper Series presents data, information, and/or findings from ongoing research and studies to encourage exchange of ideas and to elicit comment and feedback about development issues in Asia and the Pacific. Since papers in this series are intended for quick and easy dissemination, the content may or may not be fully edited and may later be modified for final publication. 


\section{CONTENTS}

TABLES AND FIGURE

ABSTRACT $v$

$\begin{array}{ll}\text { I. INTRODUCTION } & 1\end{array}$

II. GROUP SUBSIDIES AFTER THE GREAT EAST JAPAN EARTHQUAKE AND TSUNAMI 1

III. DATA 3

A. Data source 3

B. Identification of the Disaster Areas and Subsidized Firms 3

C. Construction of Variables and Samples 5

D. Descriptive Statistics 6

IV. EMPIRICAL METHODOLOGIES 8

A. $\quad$ Estimation of Direct Effects 8

B. Estimation of Indirect Effects through Supply Chains 9

V. RESULTS ON DIRECT EFFECTS 10

A. Logit Estimations and Balancing Tests 10

B. Analysis of Covariance Estimations of Direct Effects $\quad 12$

C. Distinguishing between Small and Medium-Sized Enterprises 13

VI. $\quad$ RESULTS ON INDIRECT EFFECTS

VII. DISCUSSION AND CONCLUSIONS

$\begin{array}{ll}\text { REFERENCES } & 19\end{array}$ 


\section{TABLES AND FIGURE}

\section{TABLES}

1 Definition of Small and Medium-Sized Enterprises 6

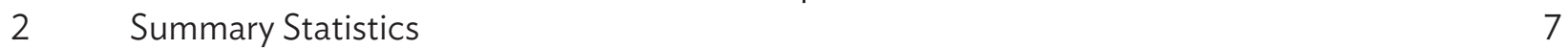

3 Logit Estimations $\quad 10$

$4 \quad$ Balancing Tests 11

5 Direct Effect of the Subsidies: All Firms 12

6 Direct Effect of the Subsidies: Comparison between Small and Medium Firms 13

7 Indirect Effect of the Subsidies within the Region: All Firms 14

8 Indirect Effect of the Subsidies within the Region: Small Firms 15

9 Indirect Effect of the Subsidies beyond the Region: All Firms 15

10 Indirect Effect of the Subsidies beyond the Region: Small Firms 16

\section{FIGURE}

Disaster Areas and Disaster-Hit Prefectures 


\begin{abstract}
This study evaluates the impact of "group subsidies," a policy intervention to repair and reinstall damaged capital goods and facilities of small and medium-sized enterprises after the Great East Japan earthquake and tsunami. In addition to their direct effect on firms that received the subsidies, we estimate their indirect effect on firms that did not receive the subsidies but were linked with recipient firms through supply chains. Employing a propensity score matching and analysis of variance approach, we find a positive effect of the subsidies on small recipient firms' postdisaster sales and employment. We also find a positive indirect effect of the group subsidies on firms in disaster-hit prefectures that did not receive any group subsidy but were linked through supply chains with a recipient firm. Our results indicate the propagation of postdisaster policy effects through supply chains, which are often ignored in the academic literature and the policymaking arena.
\end{abstract}

Keywords: natural disasters, postdisaster policy, propagation, supply chains

JEL code: H20, L14 


\section{INTRODUCTION}

When a natural disaster hits a region, the economic shock propagates to regions that are not directly hit by the disaster through the disruption of supply chains. Customers of firms directly hit by the disaster may shrink production due to lack of material, parts, or components, whereas their suppliers may mirror them due to lack of demand. The recent emerging literature on this issue found econometric evidence of such propagation, using firm-level data and supply chain information for the United States (Barrot and Sauvagnat 2016); Japan (Carvalho et al. 2016); and the world (Kashiwagi, Todo, and Matous 2018). Some other studies, such as Hallegatte (2012); Henriet, Hallegatte, and Tabourier (2012); and Inoue and Todo (2017, 2018), took another approach by using simulation analysis on an agent-based model, confirming the substantial indirect effect of disasters due to propagation. This issue has become more concerning as the frequency and severity of natural disasters is projected to increase due to climate change (Milly et al. 2002) and evolving seismic trends (Beroza 2012).

Following a natural disaster, the government and other institutions often implement policy interventions, such as subsidies and financial reliefs, to repair or reinstall damaged capital stocks and maintain employment, to alleviate its negative effect at the firm level. A few studies have examined the direct effect of such interventions on the recovery of private firms. Notably, De Mel, McKenzie, and Woodruff (2012) examined the effect of relief aid and access to capital on the recovery of microenterprises in Sri Lanka after the massive tsunami in 2004, using a randomized experiment. They find a positive effect of the interventions, particularly, on profits and revenues of retailors, but not on those of firms in the manufacturing and other service sectors. However, to the best of the authors' knowledge, no study has examined the indirect effect of postdisaster policy interventions on the performance of firms not directly hit by a disaster but linked with directly hit firms.

To fill the research gap and to contribute to postdisaster policies, this study estimates direct and indirect effects of the policy intervention, or the "group subsidies," to repair and reinstall fixed assets of small and medium-sized enterprises (SMEs) damaged by the Great East Japan earthquake in 2011 and the subsequent tsunami. We utilize comprehensive firm-level data for more than 1 million Japanese firms, containing information on approximately 5 million supply chain links among them. To avoid biases due to self-selection of recipient firms of the subsidies and unobservable factors, we employ a propensity score matching (PSM) estimation combined with an analysis of covariance (ANCOVA) approach of McKenzie (2012).

To preview our results, we find a direct positive and statistically significant effect of the subsidies on recipients' sales and employment, particularly, those small in size; and an indirect positive effect on sales of firms in the earthquake-hit region that were linked with recipients of the subsidies. Therefore, our results suggest that postdisaster subsidies to reconstruct the damaged production facilities of small enterprises can effectively facilitate their recovery and that the positive effect propagates to firms through supply chains.

\section{GROUP SUBSIDIES AFTER THE GREAT EAST JAPAN EARTHQUAKE AND TSUNAMI}

Particularly, this study focuses on a policy intervention after the Great East Japan earthquake (hereafter, the earthquake) in March 2011, the Subsidies for the Recovery of Facilities of Groups of SMEs (Chusho Kigyo tou Gurupu Shisetsu tou Hukkyu Seibi Hojo Jigyo), known as the "group subsidies" (Gurupu Hojokin). The earthquake was of magnitude 9.0 and the fourth largest earthquake in the world 
since 1900. The death toll, including the missing persons, reached 18,880 (Cabinet Office of Japan 2012). Most of the human loss were caused by the tsunami. The epicenter was off the coast of the northeastern part of Japan, a relatively less developed region where many small and medium-sized suppliers in the automobile and electric machinery industries are located (Ministry of Economy, Trade, and Industry of Japan 2011). The direct loss of economic facilities including buildings, utilities, and social infrastructure was estimated to be 16.9 trillion yen ( $¥$ ), or approximately $\$ 212$ million using the exchange rate in 2011 (Cabinet Office of Japan 2012). ${ }^{1}$

The government of Japan, through the SME agency under the Ministry of Economy, Trade, and Industry and prefecture governments, has been providing the group subsidies, henceforth referred to as "the subsidies," to groups of SMEs in areas damaged by the earthquake-from north to south, the Hokkaido, Aomori, Iwate, Miyagi, Fukushima, Tochigi, Ibaraki, and Chiba Prefectures. Specifically, this subsidy program targets SMEs that form groups to recover from the damage of the earthquake and which play an important role in the employment and economic activities in the region. The program's subsidies fulfill 75\% (50\% covered by the central government and $25 \%$ by the prefecture's government) of the costs to repair or reinstall capital goods of SMEs destroyed by the earthquake and the subsequent tsunamis (Small and Medium Enterprise Agency of Japan 2011).

A notable feature of this policy is that subsidies are provided not to individual firms but to groups of firms, such as those linked through supply chains and located in the same industrial park or the same commercial area. This policy measure was developed because subsidies were not supposed to be provided to individual firms for their own recovery from natural disasters but to groups of firms for regional recovery. Although the subsidies are provided primarily to SMEs, non-SMEs also receive the subsidies in some cases when they grouped with SMEs.

The first round of the subsidies was announced in June 2011, 3 months after the earthquake, and granted in August 2011 (Small and Medium Enterprise Agency of Japan 2011). As of December 2018, more than 7 years after the earthquake, the program continues to provide subsidies to SMEs. The size of this policy is extremely large, with a total of $¥ 504$ billion (approximately $\$ 4.5$ billion) granted to 705 groups as group subsidies by 2018.

For illustrative purposes, let us provide two examples from the first round of the subsidy program (Small and Medium Enterprise Agency of Japan 2012). In the first example, 17 firms in the electronics and precision machinery industries in the coastal areas of the Iwate Prefecture formed a group and received the subsidies; these firms were linked with supply chains and shared other business relationships. One of the recipient firms, whose five plants were completely destroyed by the tsunamis, received $¥ 700$ million (about $\$ 6.3$ million) to purchase production facilities for relocating the plant to a different location. Although this firm laid off all of 230 employees after the earthquake, it was projected to rehire 70 employees in 2012, owing to the subsidies. The second example is taken from the retail sector. Thirty retail shops in a shopping center in Iwate that were flooded by the tsunami and caught fire due to the earthquake formed a group to receive the subsidies of $¥ 670$ million (about $\$ 6$ million) to repair buildings and facilities. This subsidy facilitated the reopening of the shopping center in December 2011, 9 months after the earthquake.

The currency exchange rate applied was $\$ 1=¥ 111.95$ (as of April 2019). 


\section{DATA}

\section{A. Data Source}

This study utilizes firm-level data collected by the Tokyo Shoko Research (TSR), one of the two largest corporate research companies in Japan. The TSR data contain corporate information, such as each firm's location, sales, and the number of employees, and information on up to 24 suppliers of intermediates and up to 24 clients of products. The TSR data include the identification number of each supplier and client; we could identify the network of firms through supply chains in Japan. Although the upper limit of the number of suppliers and clients, 24, is too small for many large firms, it still captures most of the supply chain networks by considering the supplier-client relationships from both directions. The TSR data are also used in Carvalho et al. (2016) and Inoue and Todo (2017, 2018) who examine the propagation of negative shocks through supply chains after the earthquake.

Specifically, we utilize the TSR data licensed to the Research Institute of Economy, Trade and Industry in 2011 and 2014. Because most corporate information is collected a year before the year of licensing, our data cover detailed corporate information in the fiscal years 2010 and 2013. Additionally, since the TSR data include information about sales in the previous year, data on sales for the fiscal years 2009 and 2012 are available. Our TSR data for 2010 contain 1,161,096 firms and 4,971,671 supply chain links.

It should be noted that because the TSR data are at the firm level, supplier-client relationships at the plant level could not be identified. This data limitation leads to the following problem: we fail to identify earthquake-hit firms headquartered outside the disaster areas but operating a production plant in the disaster areas. However, because our analysis focuses on SMEs, of which only $19 \%$ had more than one branch (including the headquarters) in 2010, this may not substantially bias the results.

\section{B. Identification of the Disaster Areas and Subsidized Firms}

We define that firms directly damaged by the earthquake and the tsunami are those in the disaster areas hit by the earthquake or the subsequent tsunami. We identify the disaster areas using three government documents, the Act on Special Financial Support to Deal with the Designated Disaster of Extreme Severity; Article 41-2, issued on 28 April 2011 by the Ministry of Land, Infrastructure, Transport, and Tourism and provided by the Center for Spatial Information Science, at the University of Tokyo, for tsunami-flooded areas identified originally by the Ministry of Land, Infrastructure, Transport, and Tourism; and the conceptual diagram of restricted areas around the Fukushima Daiichi Nuclear Power Plant, provided by the Ministry of Economy, Trade, and Industry. The disaster areas we identified, from north to south, include four prefectures: Aomori, Iwate, Miyagi, and Fukushima, and are plotted in the figure below. 


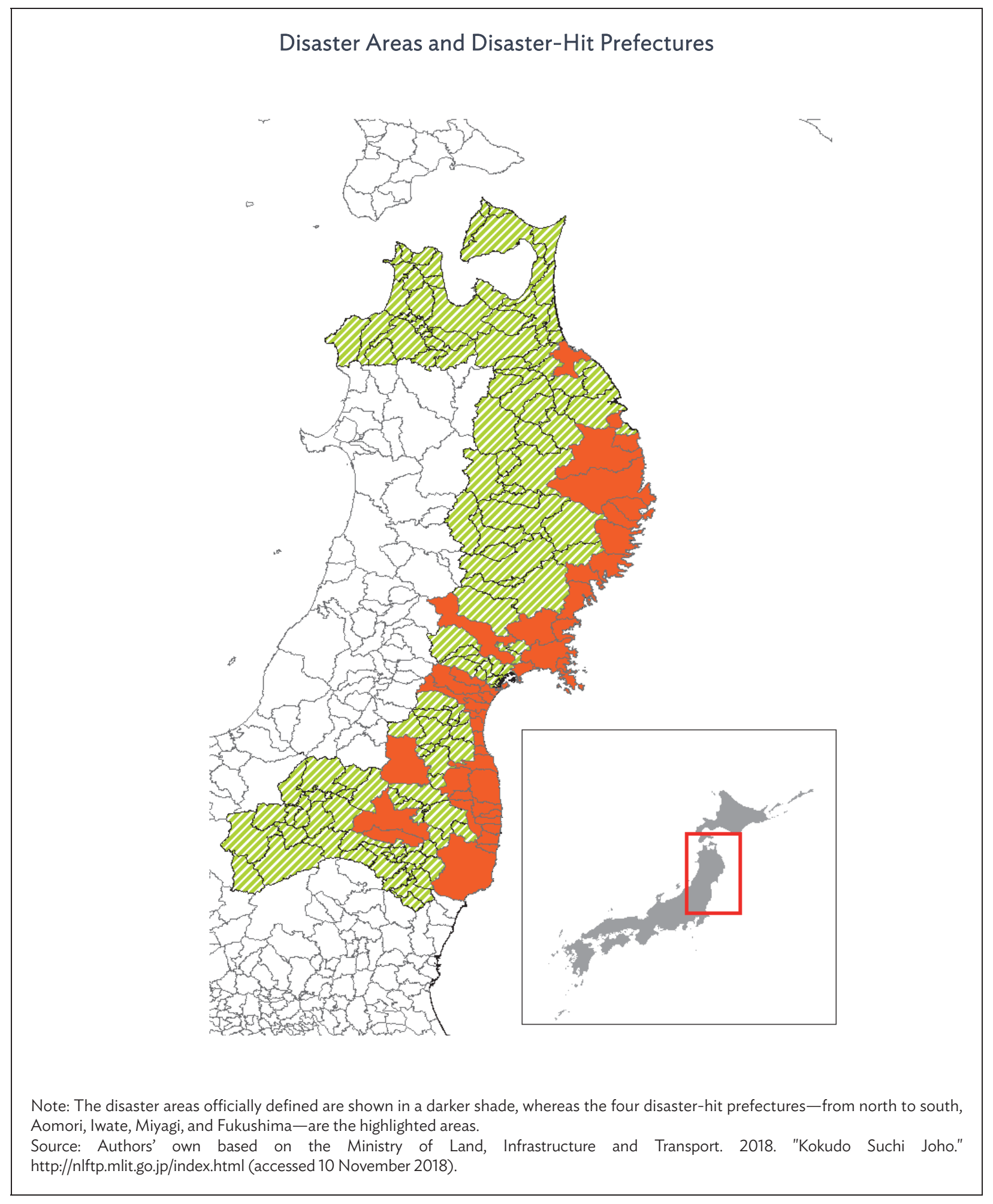


Further, we identify firms that received the subsidies, by using lists of recipient firms provided by the four prefectures' governments in the disaster areas. Because only the prefecture of each recipient firm, rather than its address, is available in the lists, we identify recipient firms in each prefecture in the TSR data using their names and corporate classifications, most notably two types of limited liability companies specific to Japan, kabushiki gaisha and yugen gaisha. ${ }^{2}$ We find a small percentage of firms in the Fukushima Prefecture, each of which is matched with more than one firm in the TSR data using only names and corporate classifications. In these cases, we chose firms in the TSR data that can be classified as SMEs according to the definition of Small and Medium Enterprise Agency of Japan (2018). Despite these efforts, we fail to accurately identify 27 subsidized firms in Fukushima in the TSR data, that is, we cannot identify $0.7 \%$ of all subsidized firms with accuracy. We drop these firms from our sample.

Following this matching process, we match $50.3 \%$ of recipients of the subsidies in the lists with firms in the TSR data. One reason for the relatively low match ratio is that many recipients of the subsidies in the lists were presented as persons' names rather than companies' names. Because we presume that these enterprises represented by persons' names are most likely microenterprises, the omission of these firms from the sample may not result in substantial biases in estimates. Another reason for the relatively low match ratio is that the TSR data cover around 53\% of all firms in Japan (Carvalho et al. 2014).

Although the subsidies were provided to SMEs in eight prefectures as presented in section III, according to the aforementioned official definition of disaster, the disaster areas were restricted to only four of the eight prefectures - from north to south, Aomori, Iwate, Miyagi, and Fukushima. Therefore, when we estimate the direct effect of the subsidies on recipient firms in the disaster areas, we ignore recipients in the four prefectures - also from north to south, Hokkaido, Tochigi, Ibaraki, and Chiba-outside the disaster areas. When we estimate the indirect effect on nonrecipients outside disaster areas, we treat recipients in the four prefectures outside the disaster areas as nonrecipients. Biases due to this assumption may be minimal as the number of recipients in the four prefectures outside the disaster areas is quite small compared to the total number of nonrecipients outside the disaster areas in 43 prefectures in Japan.

\section{Construction of Variables and Samples}

As we mentioned earlier, we use data from two time periods, 2010 and 2013. Accordingly, we utilize the following primary outcome variables: sales, number of workers, and sales per worker in 2013 . As we will explain later in detail, we will employ the PSM estimations. Our covariates in the pre-earthquake period for matching include:

1) sales,

2) number of workers,

3) firm age,

4) President's age,

5) number of plants,

6) an index of credit evaluation provided by TSR,

7) number of suppliers,

8) number of customers in 2011, and

9) sales growth from 2009 to 2010.

2 Concerning firms in the Iwate Prefecture, since cities can be identified, we also used city names for firms in Iwate, when multiple firms were matched using only firm names and corporate classifications. 
We have taken these variables directly from the TSR data. Additionally, our covariates contain dummy variables for firms hit by the tsunami, firms forced to evacuate due to the accident in the Fukushima Daiichi Nuclear Power Plant after the tsunami, and the number of SMEs in disaster-hit areas located within 1 kilometer from the focal firm. These variables can be constructed from geographic information of the officially identified tsunami-hit areas and the evacuation areas.

In several estimations, we focus either on small or on medium firms. We follow Small and Medium Enterprise Agency of Japan (2018) to define SMEs, as shown in Table 1. Because the subsidies were primarily provided to the secondary and tertiary industries, we drop entities in agriculture, forestry, and fishery, as well as public entities such as governments, academic institutions, schools, and political and religious institutions.

Table 1: Definition of Small and Medium-Sized Enterprises

\begin{tabular}{|c|c|c|c|}
\hline \multirow[b]{2}{*}{ Industry } & \multicolumn{2}{|c|}{$\begin{array}{l}\text { Small and Medium-Sized Enterprises } \\
\text { (either } 1 \text { or } 2 \text { is satisfied) }\end{array}$} & \multirow{2}{*}{$\begin{array}{c}\text { Small Firms } \\
\text { Number of } \\
\text { Full-Time Workers }\end{array}$} \\
\hline & (1) Paid-In Capital & $\begin{array}{l}\text { (2) Number of } \\
\text { Full-Time Workers }\end{array}$ & \\
\hline $\begin{array}{l}\text { Manufacturing, construction, } \\
\text { transport, and others }\end{array}$ & $¥ 300$ million or less & 300 or fewer & 20 or fewer \\
\hline Wholesale & $¥ 100$ million or less & 100 or fewer & 5 or fewer \\
\hline Retail & $¥ 50$ million or less & 50 or fewer & 5 or fewer \\
\hline Other services & $¥ 50$ million or less & 100 or fewer & 5 or fewer \\
\hline
\end{tabular}

Source: Small and Medium Enterprise Agency of Japan. 2018. White Paper on Small and Medium Enterprises in Japan.

\section{Descriptive Statistics}

The left half of Table 2 presents summary statistics for the sample of firms in the disaster areas, whereas the right half presents those for the sample of firms linked with firms in the disaster areas through supply chains. While the left half is used to estimate the direct effect of the subsidies, the right half is used to estimate the indirect effect. The average sales in 2013 in the sample for the direct effect is $¥ 486$ million (about $\$ 4.3$ million), while it is $¥ 4.99$ billion (\$44.6 million) in the sample for the indirect effect. We attribute the significant difference to the fact that the former sample includes only SMEs in the disaster areas, while the latter includes larger firms linked with firms in the disaster areas. In the 2013 sample, the average number of workers for direct effects is 17, and for indirect effects is 72.9. On average, the sample for the estimation of direct effects had 4.5 suppliers, and the sample for the estimation of indirect direct effects had 20.8 suppliers. The average number of customers for the sample for the estimation of direct effects was 4.7, while the sample for the estimation of indirect effects had 12.3 customers. In 2011, 4.6\% of the sample for the estimation of direct effects received subsidies, and $11.2 \%$ of the sample for the estimation of indirect effects were linked with subsidized firms through supply chains. In 2012, the numbers shifted, and $6.9 \%$ of the sample for the estimation of direct effects received subsidies (an increase of 2.3\%), whereas by then, only 6.2\% of the sample for the estimation of indirect effects were linked with subsidized firms through supply chains (a $5 \%$ reduction). 
Table 2: Summary Statistics

\begin{tabular}{|c|c|c|c|c|c|c|c|c|}
\hline \multirow[b]{2}{*}{ Variable } & \multicolumn{4}{|c|}{$\begin{array}{l}\text { Sample of Firms in the Disaster Areas } \\
\qquad(N=9,572)\end{array}$} & \multicolumn{4}{|c|}{$\begin{array}{l}\text { Sample of Firms Linked with Firms in } \\
\text { the Disaster Areas through Supply Chains } \\
\qquad(N=6,577)\end{array}$} \\
\hline & Mean & $\begin{array}{l}\text { Standard } \\
\text { Deviation }\end{array}$ & Minimum & Maximum & Mean & $\begin{array}{l}\text { Standard } \\
\text { Deviation }\end{array}$ & Minimum & Maximum \\
\hline $\begin{array}{l}\text { Sales } \\
\text { (\#1000, 2013) }\end{array}$ & $5.45 E+05$ & $3.02 E+06$ & 99.701 & $1.33 \mathrm{E}+08$ & $4.99 \mathrm{E}+06$ & $6.35 \mathrm{E}+07$ & 375.754 & $3.06 \mathrm{E}+09$ \\
\hline (in logs) & 11.865 & 1.464 & 4.602 & 18.705 & 12.744 & 1.953 & 5.929 & 21.841 \\
\hline $\begin{array}{l}\text { Sales } \\
\qquad(¥ 1000,2010)\end{array}$ & $4.37 \mathrm{E}+05$ & $2.51 E+06$ & 139.191 & $1.20 E+08$ & $4.35 E+06$ & $5.13 \mathrm{E}+07$ & 899.608 & $2.35 E+09$ \\
\hline (in logs) & 11.696 & 1.39 & 4.936 & 18.606 & 12.563 & 1.976 & 6.802 & 21.579 \\
\hline $\begin{array}{l}\text { Number of workers } \\
\text { (2013) }\end{array}$ & 18.256 & 67.1 & 1 & 3740.999 & 72.896 & 1098.229 & & 86207.008 \\
\hline (in logs) & 2.047 & 1.135 & 0 & 8.227 & 2.62 & 1.46 & 0 & 11.365 \\
\hline $\begin{array}{l}\text { Number of workers } \\
(2010)\end{array}$ & 17.636 & 59.225 & 1 & 2469 & 70.733 & 925.555 & 1 & 71368 \\
\hline (in logs) & 2.037 & 1.117 & 0 & 7.812 & 2.608 & 1.458 & 0 & 11.176 \\
\hline Sales growth (2010-13) & 0.169 & 0.538 & -5.975 & 4.118 & 0.181 & 0.462 & -3.523 & 3.454 \\
\hline Sales growth (2010-12) & 0.157 & 0.511 & -5.973 & 3.54 & 0.168 & 0.416 & -4.672 & 3.491 \\
\hline Sales growth (2009-10) & -0.022 & 0.304 & -2.688 & 3.658 & -0.019 & 0.318 & -6.804 & 3.26 \\
\hline $\begin{array}{l}\text { Firm age } \\
\text { (in logs) }\end{array}$ & $\begin{array}{r}28.491 \\
3.244\end{array}$ & $\begin{array}{r}14.146 \\
0.575\end{array}$ & $\begin{array}{r}1 \\
0.693\end{array}$ & $\begin{array}{r}101 \\
4.625\end{array}$ & $\begin{array}{r}33.367 \\
3.39\end{array}$ & $\begin{array}{r}17.026 \\
0.589\end{array}$ & $\begin{array}{r}1 \\
0.693\end{array}$ & $\begin{array}{r}131 \\
4.883\end{array}$ \\
\hline $\begin{array}{l}\text { President's age } \\
\text { (in logs) }\end{array}$ & $\begin{array}{l}59.92 \\
4.076\end{array}$ & $\begin{array}{r}10.575 \\
0.187\end{array}$ & $\begin{array}{r}27 \\
3.296\end{array}$ & $\begin{array}{r}101 \\
4.615\end{array}$ & $\begin{array}{r}59.614 \\
4.071\end{array}$ & $\begin{array}{r}10.475 \\
0.186\end{array}$ & $\begin{array}{r}25 \\
3.219\end{array}$ & $\begin{array}{r}98 \\
4.585\end{array}$ \\
\hline Number of plants & 0.231 & 0.572 & 0 & 11 & 0.389 & 1.245 & 0 & 54 \\
\hline $\begin{array}{l}\text { Credit evaluation } \\
\text { index }(0-100)\end{array}$ & 49.311 & 4.686 & 22 & 73 & 50.525 & 6.02 & 14 & 76 \\
\hline Number of suppliers & 4.609 & 15.841 & 0 & 781 & 20.838 & 70.865 & 1 & 2552 \\
\hline (in logs) & 1.235 & 0.895 & 0 & 6.662 & 2.148 & 1.1 & 0.693 & 7.845 \\
\hline $\begin{array}{l}\text { Number of customers } \\
\text { (in logs) }\end{array}$ & $\begin{array}{l}4.743 \\
1.423\end{array}$ & $\begin{array}{l}6.678 \\
0.776\end{array}$ & $\begin{array}{l}0 \\
0\end{array}$ & $\begin{array}{r}151 \\
5.024\end{array}$ & $\begin{array}{r}12.306 \\
1.816\end{array}$ & $\begin{array}{r}43.506 \\
1.088\end{array}$ & $\begin{array}{l}0 \\
0\end{array}$ & $\begin{array}{l}1906 \\
7.553\end{array}$ \\
\hline Dummy for small firms & 0.687 & 0.464 & 0 & 1 & 0.554 & 0.497 & 0 & 1 \\
\hline $\begin{array}{l}\text { Dummy for tsunami- } \\
\text { hit areas }\end{array}$ & 0.106 & 0.308 & 0 & 1 & 0.032 & 0.177 & 0 & 1 \\
\hline $\begin{array}{l}\text { Dummy for evacuation } \\
\text { areas }\end{array}$ & 0.009 & 0.092 & 0 & 1 & 0.003 & 0.059 & 0 & 1 \\
\hline $\begin{array}{l}\text { Dummy for subsidy } \\
\text { recipients }\end{array}$ & 0.113 & 0.317 & 0 & 1 & & & & \\
\hline $\begin{array}{l}\text { Dummy for subsidy } \\
\text { recipient in } 2012\end{array}$ & 0.04 & 0.197 & 0 & 1 & & & & \\
\hline $\begin{array}{l}\text { Dummy for subsidy } \\
\text { recipient in } 2013\end{array}$ & 0.074 & 0.262 & 0 & 1 & & & & \\
\hline $\begin{array}{l}\text { Dummy for a link with } \\
\text { any subsidized supplier }\end{array}$ & & & & & 0.111 & 0.315 & 0 & 1 \\
\hline $\begin{array}{l}\text { Dummy for a link with } \\
\text { any subsidized } \\
\text { customer }\end{array}$ & & & & & 0.062 & 0.241 & 0 & 1 \\
\hline
\end{tabular}

$\mathrm{N}=$ sample size.

Source: Tokyo Shoko Research. 2011 and 2014. "Kigyo Data File.” Tokyo Shoko Research, Ltd. http://www.tsr-net.co.jp/service/product/data_approach/ (licensed to the Research Institute of Economy, Trade and Industry in 2011 and 2014). 


\section{EMPIRICAL METHODOLOGIES}

\section{A. Estimation of Direct Effects}

We first estimate the direct effect of the subsidies on the recovery and growth of firms from the damage of the earthquake. In these estimations, we focus on SMEs in the disaster areas (see section III.B) and examine possible differences in changes in sales and employment from the pre- to the postearthquake period between firms with and without the subsidies.

There are two potential issues that may bias the estimates. First, the subsidies were not provided randomly to SMEs in the disaster areas but to SMEs that were eligible for the subsidies and were approved by prefectures' governments. Second, unobservable firm attributes, such as managers' ability and preferences, may be crucial to both firm growth and the receipt of the subsidies. These two econometric issues generate biases due to endogeneity.

To correct for such endogeneity biases, we employ a PSM procedure with a difference-indifferences (DID) estimation developed by Blundell and Costa Dias (2000). The PSM approach can correct biases due to the endogenous selection of recipients, and the DID estimation can correct biases due to unobservable firm attributes. It is often used in policy evaluation using non-experimental data. For example, Görg, Henry, and Strobl (2008) use this approach to estimate the effect of grant support to firms on their exporting activity. We further incorporate the ANCOVA by McKenzie (2012), which is found to be more efficient than fixed effects and DID estimations.

Specifically, we first estimate a logit model to examine factors that determine the participation of SMEs in the disaster areas in the subsidy program, using the pre-earthquake firm attributes, such as sales, number of workers, firm age, age of the president, 2010 credit evaluation index provided by TSR, change in the rate of sales from 2009 to 2010, number of suppliers, number of customers, number of damaged SMEs within the 1-kilometer radius (all of the above are in logs), number of plants, and prefecture dummies. We include the number of suppliers and customers and the number of neighboring SMEs because the subsidy was provided to groups of SMEs, which also comprised SMEs linked through supply chains or geographical agglomeration (e.g., retail shops in a shopping center and manufacturing firms in an industrial park).

In this first process, we divide SMEs in the disaster areas into strata at the sector level. Although our data include industry classification codes of TSR at the three-digit level, the number of subsidized firms in the sample for direct effects $(1,105)$ is too small to divide into detailed industry classifications even at the two-digit level. Therefore, we classify firms into four sectors: i) manufacturing, ii) other secondary industries, iii) wholesale and retail, and iv) other service industries.

Next, by using the estimates from the logit model for each sector, we calculate the propensity score-the predicted probability of participating in the subsidy program-given the pre-earthquake attributes. Subsequently, we match each participant firm in the program in each stratum with a nonparticipant having a propensity score closest to that of the participant. One notable issue in this matching process is that firms' fiscal year-end months vary substantially. If the fiscal year-end month is different between two particular firms, their sales and sales growth in the pre-earthquake period are defined as those in different time periods, and may thus capture different economic shocks. To avoid matching two firms with similar sales or sales growth because of different economic shocks, we match 
firms within the same sector and same fiscal year-end month. We impose a common support-we drop firms whose propensity score is outside the overlap of the two distributions of participants and nonparticipants. Additionally, we set the caliper of the difference in the propensity score at 0.05, matching two firms only when the difference between their propensity scores is less than $5 \%$. After matching, we check whether treatment firms (recipients of the subsidies) and matched controls are balanced in terms of pre-earthquake attributes, using $t$ tests.

Finally, using the matched sample, we run the following ordinary least squares estimations.

$$
\ln Y_{i t_{2}}=\beta_{0}+\beta_{1} \ln Y_{i t_{0}}+\beta_{2} \text { Subsidy } i_{i t_{1}}+D_{i} \delta+\varepsilon_{i}
$$

where $Y_{i t}$, Subsidy ${ }_{i t}$, and $D_{i}$ denote an outcome variable, the dummy variable for receipt of the subsidy, and dummy variables of firm $i$ in time $t$, respectively. We experiment with several sets of dummy variables, such as sector dummies, prefecture dummies, and fiscal year-end dummies. The time $t_{0}$ represents the pre-earthquake year or 2010, $t_{1}$ denotes the year of receipt of the subsidy or either 2011 or 2012, and $t_{2}$ denotes the postearthquake year or 2013. The outcome variables are the log of sales, number of workers, and sales per worker. Since we take a log of the outcome variables and incorporate the lagged outcome variables as an independent variable, following the ANCOVA of McKenzie (2012), we can rewrite equation (1) as:

$$
\ln Y_{i t_{2}}-\ln Y_{i t_{0}}=\beta_{0}+\left(\beta_{1}-1\right) \ln Y_{i t_{0}}+\beta_{2} \text { Subsidy }_{i t_{1}}+X_{i t_{0}} \delta+\varepsilon_{i}
$$

Therefore, we essentially estimate the effect of the subsidies on the growth rate of sales, employment, and sales per worker, considering the fixed effects included in-and the convergence represented by $-\ln Y_{i t_{0}}$. When we estimate equation (2), assuming $\beta_{1}=1$, or conduct DID estimations, we obtain similar results. Therefore, we rely on the ANCOVA approach.

In the benchmark estimations, we use all SMEs in the disaster areas. Subsequently, we focus on either small or medium firms to examine whether firm size affects the effect of the subsidies.

\section{B. Estimation of Indirect Effects through Supply Chains}

Next, we examine whether the positive effect of the subsidies propagates through supply chains. When firms had suppliers or customers that were directly damaged by the earthquake and tsunami, they may have been subjected to the indirect negative effects of the earthquake because of the disruption of supply chains, as found in the literature (Barrot and Sauvagnat 2016; Carvalho et al. 2016; Kashiwagi, Todo, and Matous 2018). However, if their damaged suppliers or customers were supported by the subsidies and thus recovered more quickly than otherwise, the indirect effect on the firms may have been smaller than when their suppliers or customers did not receive any subsidy. To estimate this indirect effect, we adopt the PSM-ANCOVA approach, similar to that in the previous section. In this examination, we deal with the following two samples-one comprising firms in the four prefectures severely hit by the earthquake-from north to south, Aomori, Iwate, Miyagi, and Fukushima-to examine the propagation of the effect of the subsidies within the region, and the other comprising firms outside the four prefectures to examine distant propagation. In each case, we utilize firms that did not receive the subsidy but were linked with firms in the disaster areas through supply chains and examine whether the performance of firms linked with subsidized firms is better than that with nonsubsidized firms. 
Specifically, we first run a logit regression to estimate determinants of links of firms with any recipient of the subsidies, given any possible link with a firm in the officially defined disaster areas, for each of the four sectors defined in section V.A. Second, using the propensity score from the logit estimations, we match each firm linked with any recipient to another firm linked with any nonrecipient within the same sector and the same fiscal year-end month. Subsequently, we run the following ordinary least squares estimation:

$$
\ln Y_{i t_{2}}=\beta_{0}+\beta_{1} \ln Y_{i t_{0}}+\beta_{2} \text { LinkSubsidy }{ }_{i t_{1}}+D_{i} \delta+\varepsilon_{i}
$$

Where LinkSubsidy is the dummy variable for any supply chain link with a recipient of the subsidies. Other variables are the same as in equation (1). In practice, we distinguish between links with recipient suppliers and customers to examine the presence of downstream (from subsidized suppliers to their customers) and upstream (from subsidized customers to their suppliers) propagation of positive effects of the subsidies.

\section{RESULTS ON DIRECT EFFECTS}

\section{A. Logit Estimations and Balancing Tests}

We start with the benchmark results for the direct effect of the subsidies on recipient firms, following the procedure explained in section IV.A. First, we run logit estimation for firms in the disaster areas in each of the four sectors. The results shown in Table 3 indicate that some of the covariates significantly affect the receipt of the subsidies. Caliendo and Kopeinig (2005) argued that the choice of the covariates significantly affect PSM estimates and suggested to exclude covariates that do not affect the treatment significantly. We experiment with various sets of covariates, for example, by dropping insignificant covariates and including squared terms, and confirm that the PSM estimates do not change significantly. Because we run similar logit estimations using several different samples later, we use the same set of covariates in any logit estimation to avoid an arbitrary choice of covariates in each estimation. Each of the covariates used is significantly correlated with the treatment variable in at least several estimations.

\section{Table 3: Logit Estimations}

Dependent variable: Receipt of the group subsidies in 2011 or 2012

\begin{tabular}{lcccc}
\hline & $(1)$ & $(2)$ & $(3)$ & $(4)$ \\
\hline Sales (log) & $0.493^{* * *}$ & 0.141 & 0.0906 & $0.204^{*}$ \\
& $(0.135)$ & $(0.117)$ & $(0.102)$ & $(0.110)$ \\
Number of workers (log) & 0.0833 & $0.244^{*}$ & $0.477^{* * *}$ & $0.214^{* *}$ \\
& $(0.138)$ & $(0.125)$ & $(0.116)$ & $(0.108)$ \\
Sales growth (2009-2010) & 0.124 & 0.0275 & -0.567 & $-0.702^{* *}$ \\
& $(0.349)$ & $(0.201)$ & $(0.390)$ & $(0.350)$ \\
Firm age (log) & $0.835^{* * *}$ & $0.573^{* * *}$ & $0.641^{* * *}$ & $0.835^{* * *}$ \\
& $(0.194)$ & $(0.159)$ & $(0.156)$ & $(0.167)$ \\
President's age (log) & -0.507 & -0.180 & -0.241 & -0.237 \\
& $(0.499)$ & $(0.359)$ & $(0.374)$ & $(0.452)$ \\
Number of plants & -0.00816 & $0.582^{* * *}$ & $0.162^{*}$ & 0.202 \\
& $(0.107)$ & $(0.170)$ & $(0.0937)$ & \\
\hline
\end{tabular}


Table 3 continued

\begin{tabular}{|c|c|c|c|c|}
\hline & (1) & (2) & (3) & (4) \\
\hline \multirow[t]{2}{*}{ Credit evaluation index } & -0.0160 & 0.0144 & -0.0190 & $-0.0422^{* *}$ \\
\hline & $(0.0209)$ & $(0.0163)$ & $(0.0204)$ & $(0.0181)$ \\
\hline \multirow[t]{2}{*}{ Number of suppliers (plus 1 and logged) } & 0.0508 & 0.136 & 0.00383 & 0.135 \\
\hline & $(0.138)$ & $(0.108)$ & $(0.0731)$ & $(0.0943)$ \\
\hline \multirow[t]{2}{*}{ Number of customers (plus 1 and logged) } & $-0.346^{*}$ & -0.0193 & 0.0991 & -0.112 \\
\hline & $(0.178)$ & $(0.114)$ & $(0.146)$ & $(0.145)$ \\
\hline \multirow[t]{2}{*}{ Tsunami dummy } & $2.583^{* * *}$ & $2.529^{* * *}$ & $2.622^{* * *}$ & $2.487^{* * *}$ \\
\hline & $(0.224)$ & $(0.149)$ & $(0.181)$ & $(0.220)$ \\
\hline \multirow[t]{2}{*}{ Evacuation dummy } & $1.820^{* *}$ & $2.731^{* * *}$ & $3.081^{* * *}$ & \\
\hline & $(0.836)$ & $(0.289)$ & $(0.804)$ & \\
\hline \multirow[t]{2}{*}{ Number of damaged SMEs within $1 \mathrm{~km}$} & -0.0358 & $-0.202^{* * *}$ & -0.0480 & $-0.312^{* * *}$ \\
\hline & $(0.0670)$ & $(0.0500)$ & $(0.0664)$ & $(0.0611)$ \\
\hline Prefecture dummies & YES & YES & YES & YES \\
\hline Number of observations & 1,103 & 4,006 & 2,438 & 2,010 \\
\hline Pseudo $\mathrm{R}^{2}$ & 0.239 & 0.254 & 0.223 & 0.214 \\
\hline
\end{tabular}

$\mathrm{km}=$ kilometer, $\mathrm{SME}=$ small and medium-sized enterprise.

Notes: Robust standard errors are in parentheses. ${ }^{* * *} p<0.01,{ }^{* *} p<0.05,{ }^{*} p<0.1$.

Source: Authors' own based on Tokyo Shoko Research. 2011 and 2014. "Kigyo Data File." Tokyo Shoko Research, Ltd. http://www.tsrnet.co.jp/service/product/data_approach/ (licensed to the Research Institute of Economy, Trade and Industry in 2011 and 2014).

After matching using the propensity scores obtained from the logit estimations, we check whether the treatment group and the matched control group are balanced. Specifically, we conduct $t$ tests to examine whether each of the covariates is systematically different between the two groups. Table 4 shows the results from the $t$ tests. The mean of the most covariates is significantly different between the treatment and the control group before matching, suggesting that recipients of the subsidies were self-selected. However, after matching, we cannot reject the null hypothesis that the mean is the same between the two groups for all covariates at $5 \%$ significance level. Therefore, we conclude that matching is appropriately achieved.

Table 4: Balancing Tests

\begin{tabular}{|c|c|c|c|c|c|c|c|c|}
\hline \multirow[b]{3}{*}{ Variable } & \multicolumn{4}{|c|}{ Before Matching } & \multicolumn{4}{|c|}{ After Matching } \\
\hline & \multicolumn{2}{|c|}{ Mean } & \multirow[b]{2}{*}{$t$ value } & \multirow[b]{2}{*}{$p$ value } & \multicolumn{2}{|c|}{ Mean } & \multirow[b]{2}{*}{$t$ value } & \multirow[b]{2}{*}{$p$ value } \\
\hline & Treated & Control & & & Treated & Control & & \\
\hline Sales (log) & 12.35 & 11.60 & 17.04 & 0.00 & 12.22 & 12.33 & -1.72 & 0.09 \\
\hline Number of workers (log) & 2.59 & 1.96 & 17.90 & 0.00 & 2.49 & 2.56 & -1.20 & 0.23 \\
\hline Sales growth (2009-2010) & -0.01 & -0.02 & 0.80 & 0.42 & -0.02 & -0.02 & -0.09 & 0.93 \\
\hline Firm age (log) & 3.44 & 3.22 & 12.05 & 0.00 & 3.41 & 3.43 & -0.71 & 0.48 \\
\hline President's age (log) & 4.08 & 4.08 & 1.20 & 0.23 & 4.08 & 4.08 & 0.37 & 0.71 \\
\hline Number of plants & 0.46 & 0.20 & 14.37 & 0.00 & 0.39 & 0.40 & -0.16 & 0.87 \\
\hline Credit evaluation index & 50.70 & 49.13 & 10.41 & 0.00 & 50.45 & 50.59 & -0.61 & 0.54 \\
\hline
\end{tabular}


Table 4 continued

\begin{tabular}{|c|c|c|c|c|c|c|c|c|}
\hline \multirow[b]{3}{*}{ Variable } & \multicolumn{4}{|c|}{ Before Matching } & \multicolumn{4}{|c|}{ After Matching } \\
\hline & \multicolumn{2}{|c|}{ Mean } & \multirow[b]{2}{*}{$t$ value } & \multirow[b]{2}{*}{$p$ value } & \multicolumn{2}{|c|}{ Mean } & \multirow[b]{2}{*}{$t$ value } & \multirow[b]{2}{*}{$p$ value } \\
\hline & Treated & Control & & & Treated & Control & & \\
\hline $\begin{array}{l}\text { Number of suppliers } \\
\text { (plus } 1 \text { and logged) }\end{array}$ & 1.47 & 1.21 & 8.98 & 0.00 & 1.41 & 1.47 & -1.25 & 0.21 \\
\hline $\begin{array}{l}\text { Number of customers } \\
\text { (plus } 1 \text { and logged) }\end{array}$ & 1.66 & 1.39 & 10.85 & 0.00 & 1.60 & 1.64 & -0.96 & 0.34 \\
\hline Tsunami dummy & 0.43 & 0.07 & 38.78 & 0.00 & 0.32 & 0.31 & 0.26 & 0.80 \\
\hline Evacuation dummy & 0.04 & 0.00 & 11.58 & 0.00 & 0.03 & 0.03 & 0.43 & 0.67 \\
\hline $\begin{array}{l}\text { Number of damaged SMEs } \\
\text { within } 1 \mathrm{~km}\end{array}$ & 3.94 & 4.25 & -7.07 & 0.00 & 3.96 & 4.01 & -0.68 & 0.50 \\
\hline
\end{tabular}

$\mathrm{km}=$ kilometer, $\mathrm{SME}=$ small and medium-sized enterprise

Notes: Robust standard errors are in parentheses. ${ }^{* *} p<0.01,{ }^{* *} p<0.05,{ }^{*} p<0.1$.

Source: Authors' own based on Tokyo Shoko Research. 2011 and 2014. "Kigyo Data File.” Tokyo Shoko Research, Ltd. http://www.tsrnet.co.jp/service/product/data_approach/ (licensed to the Research Institute of Economy, Trade and Industry in 2011 and 2014 ).

\section{B. Analysis of Covariance Estimations of Direct Effects}

Using the matched sample, we estimate equation (1) using no dummies, prefecture and sector dummies, or prefecture, sector, and fiscal year-end dummies. Our outcome variables are sales, number of workers, and sales per worker in 2013. As we take logs of all the outcome variables and use the outcome variable in 2010 in logs as an independent variable, we, essentially, estimate the effect of the subsidies on the growth rate of these variables.

The results are shown in Table 5. Using any outcome variable, the different sets of dummy variables in the set of controls result in very similar size and significance of the coefficients. These results imply that the treatment group is adequately matched with the control group so that the treatment variable is not correlated with any characteristic specific to prefectures, sectors, or fiscal year-ends. We find that the receipt of the subsidies had no effect on any of the outcome variables.

Table 5: Direct Effect of the Subsidies: All Firms

\begin{tabular}{lcccccccccc}
\hline & $(1)$ & $(2)$ & $(3)$ & $(4)$ & $(5)$ & $(6)$ & $(7)$ & \multicolumn{1}{c}{$(8)$} & $(9)$ \\
\hline Outcome & \multicolumn{3}{c}{ Sales in 2013} & \multicolumn{3}{c}{ Employment in 2013} & \multicolumn{3}{c}{ Sales per Worker in 2013 } \\
\hline Subsidies & 0.0323 & 0.0362 & 0.0362 & 0.00833 & 0.00862 & 0.00877 & 0.0164 & 0.0175 & 0.0174 \\
& $(0.0293)$ & $(0.0274)$ & $(0.0274)$ & $(0.0183)$ & $(0.0181)$ & $(0.0181)$ & $(0.0272)$ & $(0.0264)$ & $(0.0264)$ \\
\hline Lagged outcome & YES & YES & YES & YES & YES & YES & YES & YES & YES \\
Prefecture FE & NO & YES & YES & NO & YES & YES & NO & YES & YES \\
Industry FE & NO & YES & YES & NO & YES & YES & NO & YES & YES \\
Fiscal year-end FE & NO & NO & YES & NO & NO & YES & NO & NO & YES \\
\hline Observations & 1,730 & 1,730 & 1,730 & 1,730 & 1,730 & 1,730 & 1,730 & 1,730 & 1,730 \\
Adjusted R2 & 0.836 & 0.856 & 0.856 & 0.896 & 0.899 & 0.899 & 0.585 & 0.609 & 0.609 \\
\hline
\end{tabular}

$\mathrm{FE}=$ fixed effects

Notes: Robust standard errors are in parentheses. ${ }^{* *} p<0.01,{ }^{* *} p<0.05,{ }^{*} p<0.1$.

Source: Authors' own based on Tokyo Shoko Research. 2011 and 2014. "Kigyo Data File.” Tokyo Shoko Research, Ltd. http://www.tsrnet.co.jp/service/product/data_approach/ (licensed to the Research Institute of Economy, Trade and Industry in 2011 and 2014 ). 


\section{Distinguishing between Small and Medium-Sized Enterprises}

We further distinguish between SMEs, as defined in Table 1, and apply the same PSM-ANCOVA procedure as above. It must be noted that we run a logit estimation for the subsample of small or medium firms in the disaster areas and match firms within the same size category using the propensity scores from each category. Subsequently, although we do not show the results from the logit estimations or balancing tests for brevity of presentation, we confirm that the treatment and the matched control group are balanced in any PSM estimation. The results can be made available by the authors upon request. We experiment with various sets of the dummy variables, as in section VI.B, and find that the results are essentially the same. Therefore, we only show the results using the full set of the prefecture, sector, and fiscal year-end month dummies.

The results for small firms shown in columns (1)-(3) of Table 6 indicate that the subsidies to small firms had a positive and highly significant effect on sales and employment in 2013. Because both sales and employment increased, sales per capita of subsidized, small firms did not increase significantly when compared to nonsubsidized small firms. The effect is large because postearthquake sales for subsidized small firms is approximately $8 \%$ higher, and employment is $7 \%$ higher, than small nonsubsidized firms. By contrast, columns (4)-(6) of Table 6 indicate that the subsidies did not have a significant effect on either sales or employment of medium firms.

Table 6: Direct Effect of the Subsidies: Comparison between Small and Medium Firms

\begin{tabular}{|c|c|c|c|c|c|c|}
\hline & (1) & $(2)$ & (3) & (4) & (5) & (6) \\
\hline & \multicolumn{3}{|c|}{ Small Firms } & \multicolumn{3}{|c|}{ Medium Firms } \\
\hline Outcome & Sales in 2013 & $\begin{array}{l}\text { Employment } \\
\text { in } 2013\end{array}$ & $\begin{array}{l}\text { Sales per } \\
\text { Worker } \\
\text { in } 2013\end{array}$ & Sales in 2013 & $\begin{array}{l}\text { Employment } \\
\text { in } 2013\end{array}$ & $\begin{array}{l}\text { Sales per } \\
\text { Worker } \\
\text { in } 2013\end{array}$ \\
\hline \multirow[t]{2}{*}{ Subsidies } & $0.0833^{* *}$ & $0.0694^{* * *}$ & 0.0217 & -0.0261 & -0.00754 & -0.0183 \\
\hline & $(0.0387)$ & $(0.0244)$ & $(0.0399)$ & $(0.0372)$ & $(0.0290)$ & $(0.0327)$ \\
\hline Lagged outcome & YES & YES & YES & YES & YES & YES \\
\hline Prefecture FE & YES & YES & YES & YES & YES & YES \\
\hline Industry FE & YES & YES & YES & YES & YES & YES \\
\hline $\begin{array}{l}\text { Fiscal year-end } \\
\text { FE }\end{array}$ & YES & YES & YES & YES & YES & YES \\
\hline Observations & 878 & 878 & 878 & 734 & 734 & 734 \\
\hline Adjusted $\mathrm{R}^{2}$ & 0.754 & 0.798 & 0.539 & 0.858 & 0.863 & 0.742 \\
\hline
\end{tabular}

$\mathrm{FE}=$ fixed effects.

Notes: Robust standard errors are in parentheses. ${ }^{* * *} p<0.01,{ }^{* *} p<0.05,{ }^{*} p<0.1$.

Source: Authors' own based on Tokyo Shoko Research. 2011 and 2014. "Kigyo Data File." Tokyo Shoko Research, Ltd. http://www.tsrnet.co.jp/service/product/data_approach/ (licensed to the Research Institute of Economy, Trade and Industry in 2011 and 2014).

These results clearly demonstrate that the group subsidies were effective to recover small firms damaged by the earthquake and tsunami, although the same subsidies had no clear impact on medium firms. The stark contrast between small and medium firms may reflect the fact that medium firms were more likely to receive other support, such as from business partners, than small firms, which had to rely on public support, such as the group subsidies. As a result, medium firms that did not receive the group subsidy may have recovered as quickly as medium firms that received the subsidies. 


\section{RESULTS ON INDIRECT EFFECTS}

Next, we estimate the indirect effect of the group subsidies on firms linked with subsidized firms in the disaster areas through supply chains. We follow the procedure in section V.B for the two subsamples of firms-one for the firms in the four disaster-hit prefectures, and the other for those outside the four prefectures. We confirm a balance between the treatment and the match control group in each estimation but do not show the results for brevity.

First, we examine the propagation of the effect of the subsidies within the disaster-hit prefectures. In this estimation, we match each firm in the disaster-hit prefectures that did not receive the subsidy but was linked with a subsidized firm with another firm linked with a nonsubsidized firm in the disaster areas. It must be noted that the disaster areas are those officially defined to be severely hit by the earthquake and tsunami, whereas the disaster-hit prefectures are all areas in the four prefectures that include areas outside the officially defined disaster areas. We assume that supply chain links within the region are dense and strong and thus, indirect effects may be more prevalent within the region than outside the region.

Table 7 shows the indirect effect of subsidized suppliers and customers. Column (1) indicates a positive and significant effect of any subsidized supplier of the focal firm without the subsidy on the firm's sales in 2013. Precisely, postdisaster sales of firms linked with any subsidized supplier were 5.5\% higher than sales of firms linked with any supplier that were located in the disaster areas but did not receive the group subsidy.

Table 7: Indirect Effect of the Subsidies within the Region: All Firms

\begin{tabular}{|c|c|c|c|c|c|c|}
\hline & (1) & (2) & (3) & (4) & (5) & (6) \\
\hline Outcome & Sales in 2013 & $\begin{array}{l}\text { Employment } \\
\text { in } 2013\end{array}$ & $\begin{array}{l}\text { Sales per } \\
\text { Worker } \\
\text { in } 2013\end{array}$ & Sales in 2013 & $\begin{array}{l}\text { Employment } \\
\text { in } 2013\end{array}$ & $\begin{array}{l}\text { Sales per } \\
\text { Worker } \\
\text { in } 2013\end{array}$ \\
\hline $\begin{array}{l}\text { Link with subsidized } \\
\text { suppliers }\end{array}$ & $\begin{array}{l}0.0548^{* * *} \\
(0.0205)\end{array}$ & $\begin{array}{c}0.0132 \\
(0.0149)\end{array}$ & $\begin{array}{l}0.0409^{* *} \\
(0.0209)\end{array}$ & & & \\
\hline $\begin{array}{l}\text { Link with subsidized } \\
\text { customers }\end{array}$ & & & & $\begin{array}{r}0.0188 \\
(0.0161)\end{array}$ & $\begin{array}{c}0.0131 \\
(0.0115)\end{array}$ & $\begin{array}{l}0.00646 \\
(0.0163)\end{array}$ \\
\hline Lagged outcome & YES & YES & YES & YES & YES & YES \\
\hline Prefecture FE & YES & YES & YES & YES & YES & YES \\
\hline Industry FE & YES & YES & YES & YES & YES & YES \\
\hline Fiscal year-end FE & YES & YES & YES & YES & YES & YES \\
\hline Observations & 2,462 & 2,462 & 2,462 & 3,606 & 3,606 & 3,606 \\
\hline Adjusted $\mathrm{R}^{2}$ & 0.868 & 0.874 & 0.688 & 0.886 & 0.902 & 0.693 \\
\hline
\end{tabular}

Since, as we described in section $\mathrm{V}$, the direct effect of the subsidies is significant only for small firms, we particularly examine the effect of a focal firm's link with subsidized small firms on its 
postdisaster performance. The results in Table 8 demonstrate positive and significant indirect effects of links with subsidized small suppliers and customers on sales but not on employment.

Table 8: Indirect Effect of the Subsidies within the Region: Small Firms

\begin{tabular}{|c|c|c|c|c|c|c|}
\hline & (1) & (2) & (3) & (4) & (5) & (6) \\
\hline Outcome & $\begin{array}{l}\text { Sales } \\
\text { in } 2013\end{array}$ & $\begin{array}{l}\text { Employment } \\
\text { in } 2013\end{array}$ & $\begin{array}{l}\text { Sales per Worker } \\
\text { in } 2013\end{array}$ & $\begin{array}{l}\text { Sales } \\
\text { in } 2013\end{array}$ & $\begin{array}{l}\text { Employment } \\
\text { in } 2013\end{array}$ & $\begin{array}{l}\text { Sales per Worker } \\
\text { in } 2013\end{array}$ \\
\hline $\begin{array}{l}\text { Link with subsidized } \\
\text { small suppliers }\end{array}$ & $\begin{array}{l}0.0887^{* *} \\
(0.0392)\end{array}$ & $\begin{array}{c}0.00529 \\
(0.0244)\end{array}$ & $\begin{array}{l}0.0862^{* *} \\
(0.0395)\end{array}$ & & & \\
\hline $\begin{array}{l}\text { Link with subsidized } \\
\text { small customers }\end{array}$ & & & & $\begin{array}{c}0.0748^{* *} \\
(0.0373) \\
\end{array}$ & $\begin{array}{r}0.00155 \\
(0.0258) \\
\end{array}$ & $\begin{array}{c}0.0771^{* *} \\
(0.0369) \\
\end{array}$ \\
\hline Lagged outcome & YES & YES & YES & YES & YES & YES \\
\hline Prefecture FE & YES & YES & YES & YES & YES & YES \\
\hline Industry FE & YES & YES & YES & YES & YES & YES \\
\hline Fiscal year end FE & YES & YES & YES & YES & YES & YES \\
\hline Observations & 654 & 654 & 654 & 748 & 748 & 748 \\
\hline Adjusted $\mathrm{R}^{2}$ & 0.881 & 0.915 & 0.706 & 0.887 & 0.907 & 0.668 \\
\hline
\end{tabular}

$\mathrm{FE}=$ fixed effects.

Notes: Robust standard errors are in parentheses. ${ }^{* *} p<0.01,{ }^{* *} p<0.05,{ }^{*} p<0.1$.

Source: Authors' own based on Tokyo Shoko Research. 2011 and 2014. "Kigyo Data File.” Tokyo Shoko Research, Ltd. http://www.tsrnet.co.jp/service/product/data_approach/ (licensed to the Research Institute of Economy, Trade and Industry in 2011 and 2014).

Finally, we investigate the indirect effect of the group subsidies beyond the region, utilizing the sample of firms outside the four disaster-hit prefectures linked with firms in the disaster areas through supply chains. Tables 9 and 10 present the results using all SMEs and using only small firms, respectively. The results show no positive and significant indirect effect in any estimation.

Table 9: Indirect Effect of the Subsidies beyond the Region: All Firms

\begin{tabular}{|c|c|c|c|c|c|c|}
\hline & (1) & (2) & (3) & (4) & (5) & (6) \\
\hline Outcome & $\begin{array}{l}\text { Sales in } \\
2013\end{array}$ & $\begin{array}{l}\text { Employment } \\
\text { in } 2013\end{array}$ & $\begin{array}{l}\text { Sales per Worker } \\
\text { in } 2013\end{array}$ & $\begin{array}{l}\text { Sales in } \\
2013\end{array}$ & $\begin{array}{l}\text { Employment } \\
\text { in } 2013\end{array}$ & $\begin{array}{c}\text { Sales per Worker } \\
\text { in } 2013\end{array}$ \\
\hline $\begin{array}{l}\text { Link with subsidized } \\
\text { suppliers }\end{array}$ & $\begin{array}{l}0.00560 \\
(0.0254)\end{array}$ & $\begin{array}{l}-0.0125 \\
(0.0269)\end{array}$ & $\begin{array}{c}0.0187 \\
(0.0254)\end{array}$ & & & \\
\hline $\begin{array}{l}\text { Link with subsidized } \\
\text { customers }\end{array}$ & & & & $\begin{array}{l}0.00237 \\
(0.0231)\end{array}$ & $\begin{array}{c}0.0193 \\
(0.0213)\end{array}$ & $\begin{array}{l}-0.0172 \\
(0.0252)\end{array}$ \\
\hline Lagged outcome & YES & YES & YES & YES & YES & YES \\
\hline Prefecture FE & YES & YES & YES & YES & YES & YES \\
\hline Industry FE & YES & YES & YES & YES & YES & YES \\
\hline Fiscal year-end FE & YES & YES & YES & YES & YES & YES \\
\hline Observations & 938 & 938 & 938 & 1,232 & 1,232 & 1,232 \\
\hline Adjusted $\mathrm{R}^{2}$ & 0.967 & 0.938 & 0.878 & 0.969 & 0.956 & 0.822 \\
\hline
\end{tabular}

Notes: $\mathrm{FE}=$ fixed effects, $p=$ probability, $R^{2}=$ coefficient of determination. Robust standard errors are in parentheses. ${ }^{* * *} p<0.01,{ }^{* *} p<0.05,{ }^{*} p<0.1$ Source: Authors' own based on Tokyo Shoko Research. 2011 and 2014. "Kigyo Data File." Tokyo Shoko Research, Ltd. http://www.tsrnet.co.jp/service/product/data_approach/ (licensed to the Research Institute of Economy, Trade and Industry in 2011 and 2014 ). 
Table 10: Indirect Effect of the Subsidies beyond the Region: Small Firms

\begin{tabular}{lcccccc}
\hline & $(1)$ & $(2)$ & $(3)$ & $(4)$ & $(5)$ & $(6)$ \\
\hline Outcome & Sales in 2013 & $\begin{array}{c}\text { Employment } \\
\text { in 2013 }\end{array}$ & $\begin{array}{c}\text { Sales per } \\
\text { Worker } \\
\text { in 2013 }\end{array}$ & Sales in 2013 & $\begin{array}{c}\text { Employment } \\
\text { in 2013 }\end{array}$ & $\begin{array}{c}\text { Sales per } \\
\text { Worker } \\
\text { in 2013 }\end{array}$ \\
\hline $\begin{array}{l}\text { Link with subsidized } \\
\text { small suppliers }\end{array}$ & -0.0724 & -0.0573 & -0.00969 & & & \\
$\begin{array}{l}\text { Link with subsidized } \\
\text { small customers }\end{array}$ & $(0.0474)$ & $(0.0507)$ & $(0.0372)$ & & & \\
\hline Lagged outcome & YES & YES & YES & YES & YES & YES \\
Prefecture FE & YES & YES & YES & YES & YES & YES \\
Industry FE & YES & YES & YES & YES & YES & YES \\
Fiscal year end FE & YES & YES & YES & YES & YES & YES \\
\hline Observations & 266 & 266 & 266 & 226 & 226 & 226 \\
Adjusted R & & & & 0.0340 & 0.00722 & 0.0348 \\
\hline
\end{tabular}

$\mathrm{FE}=$ fixed effects.

Notes: Robust standard errors are in parentheses. ${ }^{* * *} p<0.01,{ }^{* *} p<0.05,{ }^{*} p<0.1$.

Source: Authors' own based on Tokyo Shoko Research. 2011 and 2014. "Kigyo Data File." Tokyo Shoko Research, Ltd. http://www.tsrnet.co.jp/service/product/data_approach/ (licensed to the Research Institute of Economy, Trade and Industry in 2011 and 2014).

\section{DISCUSSION AND CONCLUSIONS}

This study evaluates the impact of the "group subsidies" to repair and reinstall damaged capital goods and facilities of SMEs affected by the Great East Japan earthquake. Our innovation is that, in addition to their direct effect on firms that received the subsidies, we estimate their indirect effect on firms that did not receive the subsidies but were linked with recipient firms through supply chains. The indirect effect is worth investigating because many recent studies show that negative shocks of natural disasters propagate through supply chains (Barrot and Sauvagnat 2016; Carvalho et al. 2016; Kashiwagi, Todo, and Matous 2018). We employ a PSM-ANCOVA approach to correct for possible biases due to endogeneity and identify the average treatment effect on the treated.

We find a positive effect of the subsidies on postdisaster sales and employment of small recipient firms that are defined as those with 20 employees or less in the manufacturing sector and five or less in the service sector (Table 1) when compared to those of small nonrecipient firms in disaster areas. However, the subsidies had no significant effect on medium firms. This contrast between small and medium firms may be attributed to the fact that medium firms were more likely to receive other supports from, for example, business partners including suppliers and customers, than small firms. Therefore, there is no significant difference in postdisaster performance between medium firms supported by the group subsidies and those not supported by the group subsidies but by other means.

We also find a positive indirect effect of the group subsidies through supply chains within the four disaster-hit prefectures. In other words, sales of firms in the four prefectures that did not receive any group subsidy but were linked through supply chains with any firm in the officially defined disaster areas of the earthquake and tsunami are higher when any of their suppliers or customers received the subsidies than otherwise. 
By contrast, we find no indirect effect beyond the disaster-hit prefectures. This is possibly because firms outside the disaster-hit prefectures linked with any firm in the disaster-hit areas are larger than firms in the disaster-hit prefectures with such a link. The median number of workers for the former type, 38, is substantially larger than that for the latter, six, as only large and productive firms can reach distant partners. This logic is analogous to the fact that only large and productive firms can export, as found in the literature in international economics (Bernard and Jensen 2004, Melitz 2003). Large firms may not need to rely on public support by, for example, finding a substitute for damaged partners in the disaster areas. Accordingly, large firms linked with damaged partners without any subsidy may have recovered from the earthquake as quickly as those linked with damaged and subsidized partners. This is in line with the results of Barrot and Sauvagnat (2016) and Kashiwagi, Todo, and Matous (2018) who find an important role of substitution of partners in propagation.

Overall, our results find positive and reasonably significant direct and indirect effects of the group subsidies on firm performance. Using the estimated effects of the subsidies, we conducted a simple simulation for cost-benefit analysis. The amount of the group subsidies provided to firms in the disaster-hit prefectures in 2011 and 2012 was $¥ 380$ billion (about $\$ 3.4$ billion), and thus the amount of the subsidies to small firms, in particular, is estimated by multiplying the total amount by the share of small firms in sales, taken from the TSR data, which is $¥ 31.8$ billion (about $\$ 284$ million). The direct benefits to recipients are estimated to be $¥ 57.8$ billion (about $\$ 516$ million) by the estimated effect (the coefficient in column [1] of Table 6) ${ }^{*}$ total sales of small recipient firms in TSR / the share of recipient firms in the TSR data in the total number of recipient firms. The indirect benefits to suppliers of recipient firms are estimated to be $¥ 217$ billion (about $\$ 1.9$ billion) by estimated effect (the coefficient in column [1] of Table 8) * total sales of firms in the disaster-hit prefectures linked with small recipients. The indirect benefits to customers of recipients are estimated correspondingly. As a result, the total benefits amount to $¥ 299.1$ billion (about $\$ 2.7$ billion). This cost-benefit analysis highlights that the indirect effect through supply chains is larger than the direct effect and that the total benefit is substantially larger than the cost (although the administrative cost associated with this policy program is excluded).

Our finding on the positive indirect effect of policies through supply chains would extend the existing literature, providing an important policy implication that such indirect effects should be incorporated when postdisaster policies are evaluated. Although previous studies have found that supply chains can be a channel of propagation of negative shocks by natural disasters, this study shows that they can also be a channel of propagation of positive policy effects, mitigating negative effects of disasters. The finding of the positive role of supply chains after natural disasters is in line with Todo, Nakajima, and Matous (2015) who find their similar positive role in facilitating economic recovery from disasters by facilitating support from business partners to firms damaged by disasters. These positive roles of supply chains should not be undervalued when we consider policies for recovery from natural disasters.

However, our analysis also reveals that the group subsidies are not always effective. Particularly, we find that medium firms that did not receive the subsidy recovered as much as those that received the subsidy. This result should be interpreted with caution because we examined relatively long-term effects (effects 2-3 years after the earthquake), and ignored the immediate effects of the subsidies. However, this suggests that larger firms are more likely to receive support from other sources, such as supply chain partners, than the government. Hence, the government should be careful about providing postdisaster support to eligible SMEs to ensure the efficient use of public resources. 
As global value chains have expanded to many countries, including emerging and less developed countries (Baldwin 2016), these policy implications can be applicable to Asia, which has many SMEs that have integrated into global value chains and experiences a number of major disasters. Our analysis suggests that subsidies to firms to restore and reinstall capital goods can be quite effective to facilitate the recovery of disaster-hit regions, particularly when the region is a cluster of firms linked through supply chains, while the government may have to focus on micro and small firms as its target. 


\section{REFERENCES}

Baldwin, Richard. 2016. The Great Convergence. Boston: Belknap Press.

Barrot, Jean-Noël, and Julien Sauvagnat. 2016. "Input Specificity and the Propagation of Idiosyncratic Shocks in Production Networks." The Quarterly Journal of Economics 131 (3): 1543-92.

Bernard, Andrew B., and J. Bradford Jensen. 2004. "Why Some Firms Export." Review of Economics and Statistics 86 (2): 561-69.

Beroza, Gregory C. 2012. "How Many Great Earthquakes Should We Expect?" Proceedings of the National Academy of Sciences 109 (3): 651-52.

Blundell, Richard, and Monica Costa Dias. 2000. "Evaluation Methods for Non-Experimental Data." Fiscal Studies 21 (4): 427-68.

Cabinet Office of Japan. 2012. “Disaster Management in Japan 2012.” White Paper.

Caliendo, Marco, and Sabine Kopeinig. 2005. "Some Practical Guidance for the Implementation of Propensity Score Matching.” IZA Discussion Paper No. 1588.

Carvalho, Vasco M., Makoto Nirei, Yukiko Saito, and Alireza Tahbaz-Salehi. 2014. "Supply Chain Disruptions: Evidence from the Great East Japan Earthquake.” Unpublished paper.

_. 2016. "Supply Chain Disruptions: Evidence from the Great East Japan Earthquake." Becker Friedman Institute for Research in Economics Working Paper No. 2017-01. https://ssrn.com/abstract=2893221 or http://dx.doi.org/10.2139/ssrn.2893221.

De Mel, Suresh, David McKenzie, and Christopher Woodruff. 2012. "Enterprise Recovery Following Natural Disasters." The Economic Journal 122 (559): 64-91.

Görg, Holger, Michael Henry, and Eric Strobl. 2008. "Grant Support and Exporting Activity." The Review of Economics and Statistics 90 (1): 168-74.

Hallegatte, Stéphane. 2012. "Modeling the Roles of Heterogeneity, Substitution, and Inventories in the Assessment of Natural Disaster Economic Costs." World Bank Policy Research Working Paper 6047.

Henriet, Fanny, Stéphane Hallegatte, and Lionel Tabourier. 2012. "Firm-Network Characteristics and Economic Robustness to Natural Disasters." Journal of Economic Dynamics and Control 36 (1): 150-67.

Inoue, Hiroyasu, and Yasuyuki Todo. 2017. "Propagation of Negative Shocks through Firm Networks: Evidence from Simulation on Comprehensive Supply Chain Data." Research Institute of Economy, Trade and Industry Discussion Paper 17-E-044.

_ 2018. "Firm-Level Simulation of Supply Chain Disruption Triggered by Actual and Predicted Earthquakes." Research Institute of Economy, Trade and Industry Discussion Paper 18-E-013. 
Kashiwagi, Yuzuka, Yasuyuki Todo, and Petr Matous. 2018. "International Propagation of Economic Shocks through Global Supply Chains.” WINPEC Working Paper No. E1810.

McKenzie, David. 2012. "Beyond Baseline and Follow-Up: The Case for More T in Experiments." Journal of Development Economics 99 (2): 210-21.

Melitz, Marc J. 2003. "The Impact of Trade on Intra-Industry Reallocations and Aggregate Industry Productivity." Econometrica 71 (6): 1695-725.

Milly, Paul Christopher D., Richard T. Wetherald, K.A. Dunne, and Thomas L. Delworth. 2002. "Increasing Risk of Great Floods in a Changing Climate." Nature 415 (6871): 514-17.

Ministry of Economy, Trade and Industry of Japan. 2011. White Paper on International Economy and Trade 2011. Tokyo: Ministry of Economy, Trade and Industry. http://www.meti.go.jp/english/report/data/gIT2011maine.html.

Ministry of Land, Infrastructure and Transport. 2018. "Kokudo Suchi Joho." http://nlftp.mlit.go.jp/index.html (accessed 10 November 2018).

Small and Medium Enterprise Agency of Japan. 2011. "Chusho Kigyo Tou Gurupu Shisetsu Tou Hukkyu Seibi Hojo Jigyo Ni Tsuite (Report on Subsidies for the Recovery of Facility of Groups of Small and MediumSized Enterprises)." http://www.chusho.meti.go.jp/earthquake2011/download/110805EqSeibiSaitakuO.pdf (accessed 5 November 2018).

_. 2012. "Higashi Nihon Daishinsai Kanren Chusho Kigyo Shiensaku Katsuyo Jirei Paneru Tenji Ni Tsuite (on Panel Exibision of Examples of Utilizing Supports to Smes Related to the Great East Japan Earthquake)." http://www.chusho.meti.go.jp/earthquake2011/120302Panel.html (accessed 5 December 2018).

2018. White Paper on Small and Medium Enterprises in Japan.

Todo, Yasuyuki, Kentaro Nakajima, and Petr Matous. 2015. "How Do Supply Chain Networks Affect the Resilience of Firms to Natural Disasters? Evidence from the Great East Japan Earthquake." Journal of Regional Science 55 (2): 209-29.

Tokyo Shoko Research. 2011 and 2014. "Kigyo Data File." Tokyo Shoko Research, Ltd. http://www.tsr-net.co.jp/service/product/data_approach/ (licensed to the Research Institute of Economy, Trade and Industry in 2011 and 2014). 


\section{Propagation of Positive Effects of Postdisaster Policies through Supply Chains}

Evidence from the Great East Japan Earthquake and Tsunami

This study evaluates the impact of "group subsidies," a policy intervention to repair and reinstall damaged capital goods and facilities of small and medium-sized enterprises after the Great East Japan earthquake. A positive effect of the subsidies on small recipient firms' postdisaster sales and employment was found in the study. There was also a positive indirect effect of the group subsidies on firms in disaster-hit prefectures that did not receive any group subsidy but were linked through supply chains with a recipient firm. The results indicate the propagation of postdisaster policy effects through supply chains.

\section{About the Asian Development Bank}

ADB is committed to achieving a prosperous, inclusive, resilient, and sustainable Asia and the Pacific, while sustaining its efforts to eradicate extreme poverty. Established in 1966, it is owned by 68 members -49 from the region. Its main instruments for helping its developing member countries are policy dialogue, loans, equity investments, guarantees, grants, and technical assistance. 